\title{
Universities in Opposition to Israel's Military Occupation and the De-development of the West Bank and Gaza
}

\author{
Keith Hammond \\ University of Glasgow \\ K.Hammond@educ.gla.ac.uk
}

\begin{abstract}
This paper argues that the violation of justice in Palestine began in 1948 and was deepened in 1967 with the further occupation and de-development of Palestine which continues to this day. For forty two years, international law has been defied by Israel with one excuse after another that few people accept. Israel has persistently built more and more settlements and separations that make the basic human right to education and health near impossible for the Palestinians. Whilst international aid has been necessary, it has been politically ineffective in halting the capture and annexing of more and more Palestinian land. More Palestinians are removed from Jerusalem every day as violence upon violence is piled on the people of Palestine. This paper argues that this is unacceptable for the international family of higher education. It argues that universities around the world should take a political lead in response to the call from Palestinian and other peace workers to build the Boycott, Disinvestment and Sanctions movement in global civil society. This paper moves the position that history has built up to a point where justice for Palestine is now an undeniable global issue for people of conscience everywhere. The situation is such that universities cannot step back and leave it to politicians. Academics and students must speak out and take a lead in ending the day to day abuse of basic Palestinian rights.
\end{abstract}

\section{Introduction}

"A nation", said the French philosopher Ernest Renan, "is a group of people united by a mistaken view about the past and a hatred of their neighbours" (Shlaim, 2002). The Alternative Information Centre (AIC) in Jerusalem and Beit Sahour take the Renan position very seriously in organising both Israeli and Palestinian human rights activists in opposition to Israel's military occupation of the West Bank and almost complete closure of Gaza. Following the initiative of the Palestinian Academic and Cultural Boycott of Israel (PACBI) in 2004, the AIC now actively supports the call for a boycott of Israeli institutions servicing the occupation. The boycott initiative follows the model of the anti-apartheid movement that helped significantly to bring an end to racism in South Africa. It says the systematic de-development of the Occupied Territories and the endless denial of fundamental Palestinian rights must now end. The occupation makes education and health in Palestine almost impossible, as international volunteers and observers rarely fail to report. Palestinians cannot live as human beings under the existing conditions. This paper argues that academics and students must step up the boycott and convey to Israel that the current situation is totally unacceptable. This must be done if there is to be an end to conflict and violence. Universities around the world have to spell it out to Israel that it cannot expect to be treated as just another member of the international community in different educational forums 
whilst it creates more and more suffering for Palestine. As we all celebrate the fall of the Berlin wall, we might be reminded that another equally as pernicious wall has just been erected. Circling the entire West Bank and Gaza, the 'separation barrier' stands as a symbol of over sixty years of international indifference to the plight of Palestine. This must now end and opposition to Israel's apartheid system be built on campuses everywhere.

\section{Land Clearances and Ethnic Cleansing as Defining Activities}

Israel was created through the ethnic cleansing of 1948 (Pappe, 2006). To the shame of the British government and the rest of the international community, the whole process took place with little interference from Europe and the West. In 1967 settlements and military garrisons were established immediately after the Six Day War, taking even more land and resources from the Palestinians. The settlements and Israeli Defense Force (IDF) compounds now occupy land that carves up the West Bank. Jews only roads, around 600 checkpoints and roadblocks, plus fortified fences make it impossible to move from one place to another. Palestine is now a fragmented pattern of towns and villages that form cantons. South Africans who visit the West Bank claim the oppression that they see is much worse than that in South Africa, even at the height of Botha's hateful system. Israel's policy of annexing and de-developing the West Bank has meant that where international aid has built schools and clinics, the facilities last only as long as the next IDF round of collective punishments. Gestures of solidarity in financing new schools and so on make the conditions of the occupation a little more tolerable for a while, but rarely do they contribute to long-term justice, which is the real ongoing issue of Palestine. Palestinians do not want charity. They simply want a chance to live as other human beings, relying on their own talents and development. Palestinians recognise that the current injustice will only be changed with an international boycott. Israel will not end the occupation on its own. Peace now calls for nothing short of a South African type international boycott, which must begin in the universities.

The invasion of 1967 was supposed to have been about increasing security but the result of the war was even more Palestinian suffering, with an increase in refugees that destabilised the entire Middle East, making the whole region a more dangerous place for everyone. From 1967 a culture of denial was further consolidated in Israel. This continues as most Israeli Jewish and Druze families have amongst their members at least one full-time soldier or one in the reserves. All over Israel, young people - both male and female - move in and out of the army with complete ease. Education, employment and the military, fit around each other in the Israeli state. The military grip on the people of the West Bank and Gaza

Strip is now considered to be a part of ongoing Israeli life. The 140,000 full-time soldiers and 400,000 reservists are an integral part of the war on Palestine and many young people fit university study around their period in the armed forces. During their training these young people will carry a card stating Code of Ethics, which runs as follows: Devotion to the Mission, Responsibility, Reliability, Personal Example, Human Life, The Purity of Arms, Professionalism, Discipline, Loyalty, Worthiness to Represent Israel and Comradeship. It is a standard joke amongst those in training that once the training is over the card is thrown away. The reality of Israel's occupation of the West Bank and isolation of Gaza is a world away from considerations of justice and ethics. 
Israel is unique in functioning almost exclusively around its denials of the Palestinian people, and promotion of the victim image of Israelis. Its economy not only moves around maintaining the occupation, it also moves around the punishment of all those who resist the occupation. From June 1967, international jurists have stressed that the occupation contravenes international law (Democracy and Governance Programme, Middle East Project, 2009). Israel has rarely complied with the Geneva Convention in its treatment of the Indigenous people in the Occupied Territories and as Pappe (2006) points out, Israel has imposed endless forms of collective punishment on the Palestinians, violating just about every clause of the Convention. The scope of the crime however, is rarely appreciated outside of the Middle East. Annexation started only a few months after the Six Day War when military bases were built, first in the Jordan Valley and then all across Palestinian areas. For the Palestinians, the experience of 1967 compounded the earlier trauma of 1948. As Halper (2008) notes, the Occupation began, predictably, with physical displacement and from there some 350,000 Palestinians "most of them refugees from the 1948 war" (p. 143) had to leave their homes and refugee camps, most fleeing to Jordan. For Palestinians the expulsions of both 1948 and then 1967 must have seemed endless. After the fighting of the Six Day War subsided, 120,000 of these Palestinian refugees who had fled, then "applied to the Israeli authorities to return to their homes, their absolute right under international law" (Ibid.). The result was noted by Morris, (1999), as only 14,000 were allowed back. Land clearances in 1948 and 1967 established a clear modus operandi for Israel. As Edward Said (1992) pointed out, from 1967 on Palestine would no longer be allowed to exist. This is confirmed by Halper (2008) who notes the response of Golda Meir, claiming after 'the miracle' of 1967, "There is no Palestinian people ... there are no Palestinian refugees ... How can we return the Occupied Territories? There is nobody to return them to" (p. 143). Israeli leaders have been saying much the same thing ever since.

\section{De-development}

At the core of the occupation is the process of de-development, described in detail by Sara Roy (2004). De-development involves Israeli control of every aspect of Palestinian life, tying the social, political and economic fate of the Occupied Territories to Israel. It began with labourers, strategically being employed in the building trade by Israel in 1967. People on the West Bank began to increasingly supply the cheap labour to Israel that it needed, early in the occupation. Since then labour has been abandoned. Segev (2007) claims that as soon as Palestinian labour became useful, the minister of the interior and minister of defence decided that tighter administrative control would be needed in the form of identity cards. At the same time collective punishment emerged for those areas not complying with the new regime. Anything that aspired to an independent future for Palestine was crushed. Over the years, this has meant many schools and university buildings have been destroyed and the impact of de-development has been constantly deepened. It now shapes all Palestinian life. Yet Israel still refuses to see any parallel between what Jewish people suffered in Nazi Germany and what the Palestinians suffer in the isolated conditions of the Bantustans. Israel refuses to see the depth of the offense in blindly denying the application of international law. All this has meant that the suffering and denials go together as conditions in the Occupied Territories get increasingly worse. With reasoning that refuses to even see the Palestinians, Israel insulates itself from the reality made by checkpoints, the apartheid wall, the 
colonisation of water resources and ever more settlements. In maintaining the occupation, Israel squeezes the life out of Palestine as every expression of Palestinian resistance is seen as an 'existential threat' and subject to the same military response, involving the wholesale destruction of schools, health centres and university buildings that show no respect for Palestinian property or civilian life. What is not appreciated according to Gordon (2009) is the fact that within one month of the June 1967 invasion "the Palestinian inhabitants began mobilizing against the occupying power, organizing strikes and demonstrations" only to be met with a barrage of "military orders categorizing all forms of resistance as insurgency - including protests and political meetings, raising flags or other national symbols, publishing or distributing articles or pictures with political connotations" (p. 51). Since 1967 all forms of legitimate resistance have been squashed. The cruel irony is that the Palestinians are forced to defend themselves in ways that only brutalize their image.

Since 1967 Israel has been backed unconditionally in its hegemonic mission by the United States and indifference amongst 'first world' economies has been uncompromising. A picture has emerged showing that as Israel came into being as the Middle East super-power, Palestine has been mercilessly squeezed out of the picture. This pattern clearly depicts Israel achieving growth at the expense of marginalising Palestine. This is shown in the first move of Israeli statehood, which involved cutting Palestine off from all of its traditional trading routes, ports, and commercial, urban, and cultural centres. Thus, the state of Israel established its presence only by forcing the possibility of a Palestinian state out of the running. Under the cover of the war of independence, Palestinians were simply cleared from their land by Stern and Hagana. Israel took Palestine and rejected the Palestinian people - the first of many separations of 'forcing apart' that make Israeli apartheid. The separations in settlements, bypass roads, security zones and checkpoints show a desire to dehumanise the Palestinians that has changed little over the years. But the idea of building Israel in the image of a heroic Jewish state has meant that Israel's ethnic cleansing of 1948 had to be concealed, along with other atrocities. Ethnic cleansing is a clear crime against humanity. However, as a measure of how successful Israel has been in its cover-up, it has to be noted that ethnic cleansing is still denied by many Israeli academics. Many educated Israelis still hang on to the denials established early in the collective Israeli psyche. Now to risk repetition, it has to be underlined that one of the aims of the boycott movement is challenging these denials, which have to be confronted in every argument for justice. Only when these founding myths have been negated will there be a call for the occupation to end amongst Israelis. Avoiding fallacious narratives will only encourage more half-hearted gestures that simply avoid the sort of real justice that many European academics and university students now push towards.

\section{New Histories of Israel}

The idea of Israel has, from the beginning, worked according to the construction of ideological coherence around a project inspired in the nationalist madness of Europe (Davis, 2003). Joseph Weitz, former head of the Jewish Agency's Colonization Department wrote soon after the June 1967 War that

[b]etween ourselves it must be clear that there is no room for both [Palestinian and Israeli] peoples together in this country ... We shall not achieve our goal of being an independent people with Arabs in this small country. The only solution 
is Palestine, at least Western Palestine [west of the Jordan River] without Arabs ... And there is no other way but to transfer the Arabs from here to the neighbouring countries ... not one village, not one tribe should be left. (Rodinson, 1973, p.14)

More Israeli agreement exists around the sentiments of Weitz than is admitted in an endless mesh of denials that keep the political idea of Israel going. Where military aims end and the function of civil society begin is very difficult to discern in Israel. The fabric of denial is woven so tightly together, which means the few dissident voices inside Israel that dare to speak out against Zionism need every support that is possible in the international community, which again means challenging evasions and international indifference through the arguments for the boycott. This paper questions the wisdom of material support for Palestine that does not simultaneously support the boycott. Palestinians do not want a future dependent upon foreign aid; they want a future of autonomy and independence. This is Palestine's right and central to the call for boycott and disinvestment. Israel's occupation makes getting to and from schools and universities, not to mention clinics and hospitals, a near impossibility. Like many others, I want to argue that Israel's refusal to comply with international law must be opposed first and foremost in places of higher education. It is on the campuses that young people develop voices capable of demanding that the checkpoints and wall surrounding places like Bethlehem are dismantled. In the clearest terms possible, the boycott says that the mass expulsion of native people and the continued occupation of their land is not compatible with the values of the Universal Declaration of Human Rights and is therefore a very real crime against all humanity. It does not punish Israel in any way. The boycott simply reasserts Palestinian rights that are now missing from the Israel-Palestine equation and the first moves toward this end must include academics in the different universities.

Through the writings of Said (2003) we know European academia has never been an innocent bystander, simply observing and recording colonial injustice in the Middle East. In a dubious discourse claiming we civilised people in the West know 'you' primitive people in the East better than you know yourselves, the academies of Britain and France have contributed to the historic development of colonialism in the Middle East considerably. A stock of representations has been built up in academic centres that still influence the way we see Palestine. European and North American universities did not wake up to colonialism with the call from the Palestinian Campaign for the Academic and Cultural Boycott of Israel in 2004, which came from 50 organisations spreading right across the entire range of Palestinian civil society, all aligning themselves to this central call for quite unexceptional action. Palestine has always occupied a unique position in the thought of modern universities, standing as Palestine does, right at the edge of three continents whilst being the home of all three of the great monotheistic religions. Palestine and the Western academy have been acquainted with each other through the humanities for centuries. So it was with great interest that European academics observed the deconstruction of Israel's founding myths from the eighties in the research of those who became known as the 'new historians'. In accounting for his contribution to the writing of this new history, Morris (2001) claimed it was 1967 that disturbed old accounts of 1948, some problems having never really been given satisfactory closure in academic discourse. He said that for some years 'the Palestinian question' lay dormant but with the conclusion of the Six Day War and 
more Palestinians being made refugees, the question of 1948 was radically reawakened. The refugee problem in particular re-emerged with some force. It is difficult to imagine how things could have been otherwise, given the impact of the Six Day War on Jerusalem and the West Bank with refugee camps swelling once again.

It seemed as though overnight the names of the new historians appeared on UK undergraduate reading lists. Similar patterns were seen in France, as the names of scholars like Pappe, Segev, Shlaim and Morris began to provide the core reading of many courses. It is a point of note that up to the eighties Zionist ideology came in a form that positioned it almost outside challenge. Not so after the new or 'revisionist' historians. By accessing new private military collections and papers released after Israel's thirty-year rule of declassification, these historians uncovered a different story of 1948. Indeed they uncovered records of a hidden crime. Together, Pappe and his colleagues showed one fallacious account after another, opening up huge gaps in the old Zionist narrative. Alas, even though Benny Morris produced material detailing criminal activities in the creation of the refugee problem, he himself could not break from political loyalties inspired by old accounts. In an interview in 2004 with $\mathrm{Ha}^{\prime}$ 'artez, Morris stated that Israel's big error in 1948 was that it had not "carried out a large expulsion and cleansed the whole country - the whole Land of Israel, as far as Jordan" ( $9^{\text {th }}$ January, 2004). Whilst acknowledging new facts, implicating terror gangs in ethnic cleansing, Morris still found it impossible to change his mind about the justification of clearing Arabs from historic Palestine. He found it difficult to simply state it had been wrong to drive Palestinians out of their homes and off their land because he knew that such an acknowledgement would have raised questions about the Zionist project being morally wrong right at the beginning. Academics in the UK did not have the same difficulty. A few of them were starting to ask if the charge of ethnic cleansing held with Serbs in Bosnia, then why did it not hold in the case of Israelis in Palestine? The UN General Assembly Resolution 194 (III) of 1948 stated: The refugees wishing to return to their homes and live at peace with their neighbours should be permitted to do so at the earliest practicable date, and that compensation should be paid for the property which, under principles of international law or in equity, should be made good by the governments or authorities responsible.

Israel had avoided any serious consideration of this resolution, but after the late eighties more academics began to ask where this left Israel in international law. Millions of Palestinians still live in 1948 refugee camps. Not unaware of the way international opinion has changed, Israel still persists in ignoring Resolution 194 whilst fewer international observers find this acceptable.

\section{International Students}

Whilst debate about Israel's past has gone on, university students from the UK, Europe, Canada and the US have volunteered for summer work in refugee camps where they have witnessed the consequences of 1948 and 1967 at first hand. Many of these young people have experienced Israeli Defence Forces incursions and curfews, along with the daily impact of checkpoints and closures on civilian life. Many followed the example of Rachel Corrie and visited areas like Rafah in Gaza. Young internationals have listened to the Palestinian narrative given by one generation after another of stateless people leading to Palestine being taken up as $a$ universal cause; and returning from the West Bank, students have brought back 
stories of Palestinians still keeping the keys and deeds to their 1948 homes. Returning back to Europe, students confirm accounts of extrajudicial killings and mass arrests, recorded in endless NGO reports. Student blogs have proved to be a new source of information where the press and media have been denied chance to cover events on the ground in the West Bank and Gaza, as Palestinians have continued to demand either compensation or the right of return to their original 1948 homes. Without equivocation, they demand an end to the occupation as they refuse to acquiesce in what Jameson describes as our time's reluctance to examine its past (as cited in Foster, 1985). Palestinians forced into exile have made sure that the Palestinian story has never disappeared. The collective memory of Palestinians as proved to be a powerful ally in their fight for justice. Few people outside of Israel now fail to listen.

No matter what compromises the Palestinians have had to make, they have never abandoned the facts, which show that 1948 involved 750,000 Palestinians being driven from their homes, so that $77 \%$ of Palestinian land could become Israel. These facts were substantiated in the work of scholars like Khalidi (1991), who noted that $60 \%$ of the Indigenous population was removed from ten major towns and 416 villages, dissolving names of old Arab places on the historic map of Palestine almost overnight. The killing and violence of the Nakba or 'catastrophe' stunned the Palestinian population, and 1967 had similar impact. Both crimes took place under the cover of what was claimed to be a war, where the violence drove Palestinians in all directions. Many tried to return once the shooting subsided but they were never allowed back. The brutal details of 1948 and 1967 had to be bleached from the popular memory of Israelis, otherwise Israel's call to Jews around the world to 'return' to Israel, as part of an ethical project, would have collapsed. What this meant was that the image of Israel's army had to be maintained as one in 'a purity of arms' picture that gave structure to common Israeli beliefs about their place being in historic Palestine. However, fault lines appeared in the discourse around Haifa University - especially amongst sociologists in the early eighties. Up to that point, any hint of the IDF being involved in anything less than a noble cause could be controlled. Things began to move slightly inside the Israeli academy with the new historians.

From the 1980s the pattern shifted a little as the Palestinian narrative became a growing voice. The oral traditions of endless camps and communities resurfaced after 1967 with renewed vigour. Thus, a very different picture of 1948 began to emerge that was compounded by the more immediate injustice of 1967 . Blecher (2002) notes that in the initial run up to the West Bank occupation, Sharon had ordered his subordinates to investigate the number of buses that would be needed for transferring 300,000 Palestinians from northern Israel over to the West Bank. Sharon's plans were never quite realised because 'only' around 250,000 Palestinians were expelled (including those denied the right to re-enter the West Bank and Gaza after the invasion). Palestinians once again were "removed" on buses marked 'free passage to Amman'. According to Blecher (2002) those in the Latun area who had been moved out were sent on their way with the following words from Uzi Narkiss, the head of Central Command in 1967: "We came in the morning and said, 'everybody go to Ramallah' ... Afterward, we levelled the villages and today we have Canada Park" (p. 24). In the 2009 Israeli elections there was more discussion of the possibility of future Palestinian 'transfers' over to the West Bank and Jordan, showing a 'transfer' option had never really gone away. 
With the occupation becoming more 'normalised', the conditions of people living inside Israel have not improved. According to Cypel (2006), a staggering 58.6 of young Israelis do not complete high school. Yet most of these young people will still at some point find themselves in Israel's army where the dehumanizing values of the occupation will be absorbed with relative ease. And where the army fails, there is a whole back-up system enforcing the occupation idea in religious, ethical, legal and political forms that consolidate the military mission of the Zionist state. The army then is but one expression of a system that oscillates between the more moderate one held by academics like Islam Emmanuel Sivan, and the more aggressive position held by academics like Shimon Shamir. Cypel explains that

in Israel today, with some well known exceptions like Haim Gerber, professor of

Muslim history at the Hebrew University, the Orientalist view of the Arab-

Muslim world continues to prevail in the university departments of Near-

Eastern, Arabic, and Islamic studies - departments, moreover, that have traditionally furnished a major part of the Israeli intelligence services. (Ibid.)

Going further he writes, together, in one way or another, these views lead to a justification for dominating the Palestinian space and beyond it, the Near-Eastern region, through stigmatization of the political and social backwardness of the ArabMuslim world and what is regarded as its unprovoked natural aggressiveness against the values of Western civilization. (Ibid.)

\section{Apartheid}

The apartheid nature of the Zionist state of Israel becomes easier to discern with events following June 1967 because increasingly thereafter, the settler-colonialist project announces itself clearly in opposition to international law. Any moral understanding of the situation has to take note, difficult as this may be for the West to countenance, that policy in the Occupied Territories gets shaped on two levels: the first involves official government policy, and the second involves creating 'new' facts on the ground, neither confirmed nor denied in government policies. Yet the result is that the West Bank and Gaza are subject to one and the same military objective of more settlements and there is a tighter grip on the whole area of Gaza. After 1967 a flood of proclamations followed, vesting power in the governmental, legislative, appointative, and administrative capacities of the military commander of each area. In the seminal collection by Playfair (1992), it is noted that only weeks after June, the Israeli Government passed a law extending the boundaries of East Jerusalem to include outlying villages closer to Bethlehem and Ramallah than the former boundaries of Jerusalem. Israel then applied its law to the new captured areas, and recruited labour for the expansion of Jewish areas around Jerusalem, which had been denounced by the United Nations and almost all states as moves unacceptable in international law. Annexation, however, was to be openly endorsed in 1980, when the Israeli Knesset declared 'Jerusalem in its entirety' (i.e. West and East Jerusalem combined) was to be the 'eternal capital' of Israel. It is interesting to note that subsequent arguments for retaining all or part of the Occupied Territories have been made with little difference by both Labour and Likud governments alike. One of the very first plans put forward for the newly conquered Territories was one put forward by Israel's Minister of Labour, Yigul Allon and whilst the Allon Plan was never formally endorsed, it was de facto policy for expanding settlements in the years up to the late seventies. Also in these early days of the occupation, the religious group Gush Emunim, followed suite and put 
its own settlement plan into action that was even more extensive than the Allon plan. Gush Emunim made its intention to settle its people all across historic Palestine with almost no government opposition. The Israeli army had set the pace before all else, when it began demolishing houses in Jerusalem well before hostilities of the Six Day War had finished. Settlement expansion took place immediately after 1967 and continued a steady pace until the Oslo years, when settlement appeared all over the West Bank and Gaza.

Israel in fact had to slow down its plans for the Old City of Jerusalem because of Christian concern about damaging religious sites. This however, did not stop Israel from demolishing housing in the Arab Quarter of the Old City. Halper (2008) describes the scene in the middle of the June 1967 War as 'wanton' when having no jurisdictional authority over the occupied eastern part of Jerusalem but

with the active cooperation of the army, West Jerusalem mayor Teddy Kollek ordered the destruction of the Arab Mughrabi Quarter of the Old City, situated at the entrance of the Wailing Wall. The army provided the bulldozers, although the operation had nothing whatsoever to do with either the hostilities or security. In the middle of the night, Lieutenant Colonel Yaakov Salman ordered the 135 families of the neighbourhood roused from their beds. Given just a few minutes to evacuate their homes, some refused to leave. Salman ordered the Engineering Corps to begin the demolition anyway, killing one elderly woman named Hajji Rasmia Tabak. Israel immediately assumed responsibility for the occupied residents of Jerusalem, undertaking the administration of the major civil institutions like education, healthcare, welfare and the financial and legal systems. By September the first Jewish settlements were built. At the same time, 28 villages were annexed to Jerusalem and Israel immediately began expropriating more Palestinian land and water resources. In the first twenty years of the occupation a further 125 Israeli settlements were built. These early moves brought the entire West Bank and Gaza population of approximately one million Palestinians under military control.

\section{First the Land and Then the Law}

In the first four years of the occupation around 400 'core orders' were laid down, relating to the production and movement of Palestinians for the import and export of goods. For Israel, the West Bank and Gaza became a captured market. Cheap commodities could flood the area according to Israel's needs. Goods coming into the West Bank from Jordan stopped almost overnight (Ryan, 1972). Some fifteen hundred military orders regulating endless aspects of life - civilian, economic and political - were issued to cover the next 25 years (Rosenfeld, 2004). Almost overnight unskilled Palestinian labour was absorbed into Israel. According to Ryan, training programmes gave Palestinians just enough skill to work under an Israeli foreman. In 1968, 6\% of the Palestinian workforce was employed in Israel. By 1974 this figure had risen to 69,400, a staggering 33\% of the workforce. Whilst Palestinians had more disposable income, they could not exercise any sort of purchasing power that contributed to the building of an autonomous Palestinian economy. Severe legal restriction had been placed on Palestinian production over this same period of time. According to instructions in the Jerusalem Post (October 22 , 1967) special permits had to be obtained by the Palestinians from the Israelis, saying goods would not result in an Israeli surplus, which would disadvantage Israeli producers. Yet by 1986 there were 108,900 Palestinians dependent on work in Israel-some $39.2 \%$ of the workforce, constituting a situation unparalleled in the 
rest of the world. All of this emerged at the same time as Palestinian land disappeared in the form of new settlements and 'Jews only' roads linking the different settlements.

Settlements were built at a startling pace following the ideological encouragement of the World Zionist Organization. The idea behind the Drobles Plan in 1977 was further fragmentation of the Palestinian population centres, so that no future Arab control could be established in the region. The Bantustan option had been exercised and in a relatively short period of time. The whole project was concealed in some extremely persuasive language, which nonetheless focused on settlements "throughout the entire Land of Israel" (Mallison \& Mallison, 1986, p.446). The plan was framed in terms of Israel's 'security' and natural right. Again, the subtext was all about acquiring the land without acquiring the population, implying that the transfer solution was up for consideration once again. Blecher (2002) notes a poll of March 2002 administered by Tel Aviv University, showing that 46 percent of Israel was still in support of transfer for Palestinians from the West Bank to either Jordan or elsewhere and 31 percent advocated the same treatment for Palestinian citizens of Israel. A staggering 60 percent were reported as saying they supported 'encouraging' Palestinian Israelis to leave Israel and a full 80 percent objected to the inclusion of Palestinian Israelis in decisions of national importance (Ibid.). The poll confirmed that many ordinary Israelis shared the views of Benny Morris. The strategy followed in the ethnic cleansing of 1948 and 1967 was still being considered in comparison with the dangerously threatening rhetoric of the 2009 Knesset elections. The rhetoric simply fed fear behind transfer e policies.

Simply defined, 'closures' deny Palestinians movement through checkpoints and involve a pass system, first introduced in 1991, which was extended and further refined throughout the Oslo years. For students and staff trying to get to and from university, life becomes unworkable. In accordance with this strategy, the Gaza Strip is closed off from the rest of the world by air, sea and land. No one gets in or out of Gaza without advance Israeli approval. Not even simple building materials are allowed into Gaza. Since the election of Hamas in 2006, the movement of people and services is extremely rare. Thus, whilst settlements are built well inside the West Bank with a 'Jews only' network of linking roads, the Palestinians are 'separated off' in Bantustans. Collective punishment for violating the closure policy is harsh. According to Gordon (2008), "during the six-year period 2001 to 2007 Israel has, on average, killed more Palestinians per year than it killed during the first 20 years of the occupation" (p.25). Gordon goes on to state, "since the eruption of the second intifada Israelis have killed almost twice as many Palestinians as they killed the preceding 34 years" (Ibid.). With the increase in killing has come a different form of control affecting the overall brutality of the occupation. While both Israeli and Palestinian deaths have increased, it is notable that they have not increased to anything to the same degree. Gordon argues that the interactions, excesses and contradictions produced by the means of control in the occupation, now explain dramatic changes that have taken place over the years since 1967. Gordon claims

we are currently witnessing a macabre politics characterised by an increasing number of deaths. The change has come about through changes in Israel's 'methods' of upholding the occupation, replacing a politics of life, which aimed to secure the existence and livelihood of Palestinian inhabitants, with a politics of death. (Gordon, 2008, p. 2-3) 
That the occupation is now about the management of death and destruction is also argued by Ghanim, who makes the point that because the threat of death hangs over the Occupied Territories constantly the granting of life becomes a tremendous 'favour' (Ghanim, 2006).

\section{Impossible Development}

In these conditions, international collaborations with Palestinian education become impossible. Rejecting Israel's policy however means challenging dedevelopment. It means rejecting Israel's racial and religious discrimination. The Palestinian people have rights that are simply being waived and international law is being asked to look the other way. Writing just before the Second Intifada, the Palestinian Economic Policy Research Institute and the World Bank (1999) outlined what changing the situation would have to mean. The institute emphasised that the domestic production on the West Bank and Gaza had never been strong but data for the closing of the second millennium showed pockets of extreme poverty in various refugee camps dotted all over the West Bank and Gaza, where the development of the Palestinian infrastructure has been consistently shaped around the racist needs of settlements. However, the number of Palestinians working in Israel remained steady right up to the mid-1980s. This created a heavy reliance on Israel around four factors:

i) Asymmetric market relations with Israel.

Manual labour and manufacturers had free access to Israel, as did skilled labour elsewhere but the expansion of agriculture and manufacturing in Palestine was restricted at the same time as more resources were taken up by the expansion of settlements. There were restrictions of every kind on global trading, and trade between Palestine and Jordan was very tight because trading still had to go through Israel. Israeli trade conditions were highly protectionist right up to the mid 1980s, whilst there has rarely been any restriction on imports from Israel. Recent reports show out of date consumables are sold en masse by settlement 'entrepreneurs' as they flood Palestinian areas after these goods have passed the date by which they can be sold in Israel. The Palestinian infrastructure could not develop in these conditions.

ii) Restrictions on the Palestinian private sector.

Medium and large private firms have been purposely held back by Israeli 'regulation restrictions' - especially investment approvals required by the Israeli Civil Administration, an uncertain and punishing legal and taxation framework that is loaded with political risk. The Palestinian financial system had to be closed down completely in the early 1990s because it was unworkable. The accumulative impact of each of these measures has meant that Palestine has inclined increasingly towards the export of labour as its prime method of generating income. Of course this scenario enforces the idea that the Palestinians are lazy and quite unlike their driven Israeli neighbours. The Arabs are simply seen as without initiative.

iii) Fiscal compression and institutional under-development.

Public goods are scarce in Palestine because of the low tax receipts - a 'close-tobalanced budget' practice has been maintained rigidly by the Israeli Civil Administration and municipalities. An inability to utilise or borrow to invest policy was imposed on Palestine - in contrast to the rest of the world's practices. Recent events on Wall Street and in the City of London show how economic growth is dependent on sound credit facilities. In effect, Palestine was kept out of anything 
positive that might be incurred through globalization. "Public sector revenues were low at 16 percent of the GDP - partly because a portion of Palestinian tax payments, perhaps as much as 10 percent of the GDP, accrued to the Israeli treasury", reports the Palestine Economic Policy Research Institute and the World Bank (1999, p. 9). I use these figures to show a pattern of more enduring significance that has been the situation since the 1980s. Of course since1999 it has become much worse.

iv) Restrictions on access to natural resources.

The illegal, internationally denounced wall around the West Bank goes well beyond the 1967 Green Line, capturing valuable water resources and even more fertile agricultural land. The Jordan Valley (known as the 'fruit basket' of Palestine) is now completely inaccessible for Palestinians, as are all the areas around which settlements have been built. The Jews-only roads linking the different settlements to each other and to Israeli cities, like Tel Aviv, reduce Palestinian land and movement even further. It is interesting to note that this year there have been more links between the different settlements than ever before. This 'technically' does not involve the building of new settlements but it does involve more land being taken up by settlement communities. Like the checkpoints and roadblocks, the settlements have grown increasingly, often by default, with every round of peace talks. The pattern was established with Oslo. Settlement expansion has taken up more and more Palestinian land and resources - including educational resources, for instance in the building of the wall around Al Quds University.

\section{Boycott, Disinvestment and Sanctions (BDS)}

The International Court of Justice at The Hague in 2004 ruled against the apartheid wall. This ruling has been completely ignored by Israel. International law is weakened with this gesture, one of many other gestures that suggest Israel sees itself as outside of international law. Israel ignores these rulings and pushes on with its illegal project of colonialism and apartheid. Whilst Israel ignores the international community, the international community does not ignore Israel. Academia has been involved in narrating accounts of historic Palestine for centuries. Many of these representations were negative, as Edward Said pointed out. In the second part of the twentieth century - possibly on account of diasporic voices like that of Said - institutions like those of higher education in Europe and North America have become increasingly aware of the injustice dropped on the Palestinian people with the Zionist project. Ignoring the injustice has created nothing but further injustice. Palestinian universities came into being in impossible conditions, and yet they have against all odds, and often in complete isolation, continued to function. But as is the case with the rest of Palestine, they have never been allowed to develop according to their right. De-development has been pursued by Israel and backed up unconditionally by Europe and the United States. De-development has burdened social and economic progress in Palestine to the point where colleagues in Palestine move from one crisis to another, not knowing when their campuses will be surrounded by the Israeli military and when they will be closed down again. Children, preparing for university in the United Nations Reliefs and Works Agency for Palestine Refugees in the Near East (UNWRA) schools barely get enough to eat. They arrive at school not knowing if the building will still be there. All this amounts to a situation that is intolerable. Yet the 
community remains quiet. Key institutions and well-known academics now need to speak out and bring Israel to its senses. The situation has been allowed to go for far too long.

Under cover of a war of independence, the Palestinians were ethnically cleansed in 1948 and then again in 1967 as Israel celebrated the miracle of victory in the Six Day War. Endless illegal settlements followed and they are being expanded still to this day. Since 1967, de-development has been enforced on the Palestinian people, squeezing all life out of the West Bank and Gaza. With 9/11 and Sharon's subsequent orgy of killing, the horror of suicide bombings met with even more military violence. Israel has created a reality that will continue until responsible people like academics face up to the suffering of this situation and speak out, which is now happening with the international Boycott, Disinvestment and Sanctions (BDS) movement. International organisations of civil society are following the example of those who boycotted racist South Africa. The BDS is being built by Jewish anti-Zionists everywhere who say that Israel left to its own ideological devices will only continue the injustice and produce more and more violence. Only international action amongst academics and students will change the current conditions. In the most peaceful way possible that is open to people of conscience, a grassroots movement must be encouraged that says no to all the cosy collaboration with Israel. Academics and students have taken a lead that is allowing everyone to rediscover the importance of justice and the absolute need to speak out against Israel's occupation. This surely is worthy of support.

\section{References}

Democracy and Governance Programme: Middle East Project. (2009). Occupation, colonialism, apartheid? A re-assessment of Israel's practices in the Occupied Palestinian Territories under International Law. Cape Town: Human Sciences Research Council.

Flapan, S. (1979). Zionism and the Palestinians. London: Croom Helm.

Gerstenfeld, M. (2006). European-Israeli relations: Between confusion and change? Jerusalem: Jerusalem Center for Public Affairs.

Gordon, N. (2008). From colonization to separation: Exploring the structure of Israel's occupation. Third World Quarterly, 29(1), pp. 25-44.

Halper, J. (2008). An Israeli in Palestine. London: Pluto Press.

Jameson, F. (1985). Postmodernism and consumer society. In H. Foster (Ed.), Postmodern Culture. London: Pluto.

Keating, M., Le More, A. \& Lowe, R. (2005). Aid, diplomacy and facts on the ground: The case of Palestine. London: Chatham House, Royal Institute of International Affairs.

Kimmerling, B. (2006). Politicide: The real legacy of Sharon. London: Verso.

Kimmerling, B. \& Migdal, J. (1993). Palestinians: The making of a people. New York: Free Press.

Laquer, W. \& Rubin, B. (Eds.). (2001). The Israel-Arab reader. New York: Penguin.

Lentin, R. (2008). Thinking Palestine. London: Zed Books.

Mallison, W.T. \& Mallison, S.V. (1986). The Palestine problem in international law and world order. Harlow: Longman. 
Masalha, N. (1992). Expulsion of the Palestinians: The concept of 'transfer' in Zionist political thought: 1882-1948. Washington, DC: Institute for Palestine Studies.

Morris, B. (1987). The birth of the Palestine refugee problem. Cambridge: Cambridge University Press.

Morris, B. (1999). Righteous victims: A history of the Arab-Israeli conflict: 18811999. New York: Knopf.

Morris, B. (2001). Righteous victims: A history of the Zionist-Arab conflict: 18812001. New York: Vintage Books.

Pappe, I. (1992). The making of the Arab-Israeli Conflict: 1947-1951. London: I. B. Tauris.

Pappe, I. (1997). Post-Zionist critique on Israel and the Palestinians - Part I: The academic debate. Journal of Palestinian Studies, Winter 1997(2), pp. 29-41.

Pappe, I. (2006). The ethnic cleansing of Palestine. Oxford: One World Publication.

Playfair, E. (1992). International law and the administration of occupied territories. Oxford: Clarendon Press.

Roberts, A. (1988). Decline of illusions: The status of the Israeli-Occupied Territories over 21 years. International Affairs, 64(3), pp.345-359.

Rodinson, M. (1973). Israel: A colonial-settler state? New York: Pathfinder. Translated from the French by David Thorstad.

Rosenfeld, M. (2004). Confronting the occupation. Stanford: Stanford University Press.

Roy, S. (2004). The Gaza Strip: The political economy of de-development. Washington, DC: Institute for Palestinian Studies.

Ryan, S. (1972). Constructing a new imperialism: Israel and the West Bank, Middle East Research and Information Project, May-June 1972(9), pp. 3-11 + 17.

Said, E.W. (1992). The question of Palestine. London: Penguin.

Said, E.W. (2002). The end of the peace process. London: Granta Publications.

Said, E.W. (2003). Orientalism. London: Penguin Books.

Segev, T. (2007). 1967: Israel, the war and the year that transformed the Middle East. London: Abacus.

Shlaim, A. (1988). Collusion across the Jordan: King Abdullah, the Zionist movement and the partition of Palestine. Oxford: Clarendon Press.

Shlaim, A. (2002). A betrayal of history. Guardian.co.uk. Retrieved from http://www.guardian.co.uk/world/2002/feb/22/israel

Zureik, E. (1996). Palestinian refugees and the peace process. Washington, D.C.: Institute for Palestinian Studies. 